\title{
Correction to: Anti-CD40 antibody KPL-404 inhibits $T$ cell-mediated activation of $B$ cells from healthy donors and autoimmune patients
}

\author{
John Marken ${ }^{1}$, Sujatha Muralidharan ${ }^{2^{*}}$ and Natalia V. Giltiay ${ }^{1^{*}}$
}

\author{
Correction to: Arthritis Res Ther (2021) 23:5 \\ https://doi.org/10.1186/s13075-020-02372-z
}

Following publication of the original article [1], a typesetting error was reported. The affiliations for Sujatha Muralidharan and Natalia V. Giltiay are as follows:

Sujatha Muralidharan: Kiniksa Pharmaceuticals Corp,

Lexington, MA 02421, USA

Natalia V. Giltiay: Division of Rheumatology,

Department of Medicine, School of Medicine,

University of Washington, 750 Republican St, Seattle,

WA 98109, USA

The original article [1] has been corrected.

Published online: 21 January 2021

\section{Reference}

1. Marken J, Muralidharan S, Giltiay NV. Anti-CD40 antibody KPL-404 inhibits T

cell-mediated activation of $B$ cells from healthy donors and autoimmune patients. Arthritis Res Ther. 2021;23:5 https://doi.org/10.1186/s13075-02002372-z.

The original article can be found online at https://doi.org/10.1186/s13075020-02372-z

*Correspondence: SMuralidharan@kiniksa.com; giltiayn@uw.edu

${ }^{2}$ Kiniksa Pharmaceuticals Corp, Lexington, MA 02421, USA

'Division of Rheumatology, Department of Medicine, School of Medicine,

University of Washington, 750 Republican St, Seattle, WA 98109, USA

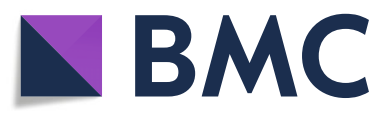

( The Author(s). 2021 Open Access This article is licensed under a Creative Commons Attribution 4.0 International License, which permits use, sharing, adaptation, distribution and reproduction in any medium or format, as long as you give appropriate credit to the original author(s) and the source, provide a link to the Creative Commons licence, and indicate if changes were made. The images or other third party material in this article are included in the article's Creative Commons licence, unless indicated otherwise in a credit line to the material. If material is not included in the article's Creative Commons licence and your intended use is not permitted by statutory regulation or exceeds the permitted use, you will need to obtain permission directly from the copyright holder. To view a copy of this licence, visit http://creativecommons.org/licenses/by/4.0/. The Creative Commons Public Domain Dedication waiver (http://creativecommons.org/publicdomain/zero/1.0/) applies to the data made available in this article, unless otherwise stated in a credit line to the data. 